\title{
EFL TEACHER CANDIDATES' ENGAGEMENT IN MOBILE-ASSISTED FLIPPED CLASSROOM
}

\author{
Truly Almendo PASARIBU \\ ORCID: 0000-0003-4243-6673 \\ English Language Education Study Program \\ Universitas Sanata Dharma \\ Yogyakarta, INDONESIA \\ Mega WULANDARI \\ ORCID: 0000-0001-5231-8641 \\ English Language Education Study Program \\ Universitas Sanata Dharma \\ Yogyakarta, INDONESIA
}

Received: 03/06/2020 Accepted: 20/11/2020

\begin{abstract}
Many studies have explored the benefits of flipped classrooms in language learning, but a further investigation on the link between mobile-assisted flipped classrooms and EFL teacher candidates' engagement in learning in an Indonesian context is needed. This research aimed at elaborating on how the implementation of mobile-assisted flipped classroom engaged EFL teacher candidates. With this goal in mind, we employed a case study design aiming at giving a holistic description of the case. It included multiple sources of data from online archives, observations, questionnaires, and Focus Group Discussion (FGD). We investigated the roles of the teacher and the students in the implementation of a mobile-assisted flipped classroom. The data from online archives, observations, questionnaires, and FGD show that a flipped course leads to EFL engagement. The discussion reveals how EFL teacher candidates experience different levels of emotional, behavioral, cognitive, social, and reflective engagements in various modes of learning and interactions. The study elaborates on the positive impact of mobile-assisted flipped language learning on engaging teacher candidates. This study also offers some implications and recommendations for teaching practitioners and future research.
\end{abstract}

Keywords: MALL, flipped classroom, language teaching, EFL teacher candidates.

\section{INTRODUCTION}

Extensive literature has discussed the benefits of learning and teaching a language with technology. Technology is believed to have enhanced language teaching (Basal, 2015; Cakir, 2013; Franklin, 2011; Giron-Garcia, 2015; Lee \& Wallace, 2018a; Yang, Chuang, Li, \& Tseng, 2013). The use of technology in an Indonesian context fosters students' autonomy (Ardi, 2017; Wulandari, 2017), raises their writing engagement (Prasetyawati \& Ardi, 2020), reduce anxiety (Pasaribu, 2016), and improves critical thinking skills (Pasaribu \& Iswandari, 2019). Not only does it empower students' learning process, but technology facilitates teaching for developing materials, instructional testing, and assessment. Turan and Akdag-Cimen (2020) conducted a systematic review of the studies of flipped models and revealed that flipped models increased student engagement. However, the integration of technology in Indonesia remains low (Harendita, 2013) because in the process of implementing technology teachers face some challenges.

Despite the benefits of learning and teaching language using technology, some teachers are still resistant to using technical tools due to their teaching beliefs and limited resources. First, the teacher-centered approach has been considered "commonplace in Indonesian school culture" (Zulfikar, 2009, p. 19). In Indonesia, the word guru (teacher) stands for digugu lan ditiru or obeyed and imitated (Ardi, 2017; Herawati, 2010; 
Pasaribu, 2020). Because teachers are culturally seen as the main source of information, both teachers and students may feel demotivated to find other sources using technology. Moreover, some teachers also felt anxious in using technology since they are categorized as digital immigrants teaching students who are born in the digital culture. Yunus et al. (2013) pointed out that some teachers also argued that technology can make the students lazy due to their reliance on technology. Another barrier is the lack of hardware, software, and Internet facilities in schools. Not all schools are equipped with adequate digital tools. A limited Internet connection can also demotivate teachers to use technology.

These constraints should be a major concern for educators in the Industrial Revolution 4.0. To meet current pedagogical objectives, teachers should be able to integrate technology into English classrooms (Cakir, 2013; Danker, 2015; Gilbert, 2013). Seeing this need, pre-service teachers must be equipped with technology, pedagogy, and content knowledge (TPACK). This concept has been introduced to describe an integrated conceptual framework for the knowledge base that teachers or preservice teachers must possess to effectively teach with technology in classroom settings (Harris, Koehler, Koehler, \& Mishra, 2009; Koehler, 2006). Gonen (2019) scrutinized pre-service teachers' and students' reflections and discovered that technologyenhanced classes help improve language skills. He also mentioned that it enhanced motivation and active participation. Due to the benefits of technology in language learning, Indonesian preservice teachers or EFL teacher candidates should actively experience the classroom which implicitly exposes this knowledge in the teaching and learning process. To enable EFL teacher candidates to use, apply, and assess digital media for language learning, we investigated a study program which offers Computer Assisted Language Learning (CALL), an elective course offered to sophomore students in the English Language Education Study Program, Faculty of Teacher Training and Education, Sanata Dharma University, Indonesia.

Studies have discussed the link between technology in flipped classrooms and learning (Chen Hsieh, Wu, \& Marek, 2017; Davies, Dean, \& Ball, 2013; Hung, 2015; Jarvis, Halvorson, Sadeque, \& Johnston, 2014; Lee \& Wallace, 2018b; Steen-Utheim \& Foldnes, 2018). Flipped classrooms place students in the center of learning implementation. A flipped classroom is a learning model where traditional teaching procedures are reversed (Hung, 2015). Hsieh, Wu, and Marek (2017) elaborated on how flipped models help students achieve the learning goals as the research participants improve their idiomatic acquisition significantly in the flipped learning context. Davies, Dean, and Ball (2013) explored how a flipped classroom motivates learning. Steen-Utheim and Njål Foldne (2018) showed how the affective dimension of student engagement is particularly prominent when students reflect upon learning in the flipped classroom when studying mathematics. Lee and Walace (2018) also highlighted the benefits of a flipped classroom for students' enjoyment and engagement.

A sizable number of studies have emphasized the benefits of flipped classrooms. However, there is little investigation on the link between mobile-assisted flipped classrooms and EFL teacher candidates' engagement in learning in an Indonesian context, so further studies are needed. This study fills the literature gap by exploring how web technology in a flipped classroom was implemented to lead to EFL teacher candidates' engagement in learning. The course utilized a Moodle 3.6 format responsive to mobile phones through the Moodle application (app) and browsers. Different digital tools and language skills are integrated in developing the materials for this class. EFL teacher candidates are required to create language learning lesson plans using different digital tools. This study also aimed at explaining how mobile-assisted flipped classrooms are linked to EFL teacher candidates' engagement. Fredricks et al. (2004) categorized engagement into three domains: behavioral engagement, cognitive engagement, and emotional engagement. Besides using this framework in analyzing the data, this study also analyzes different kinds of engagement in the class within the socio-cultural context of the university. Students' social engagement and reflective engagement, which are central in learning and teaching languages, are also scrutinized. The discussion has critical implications for educators to gain a deeper understanding of EFL teacher candidates' engagement. Suffice it to say that investigating how the implementation of a mobile-assisted flipped classroom fosters student engagement is crucial. The research aims at answering this research question: how did the implementation of a mobileassisted flipped classroom engage EFL teacher candidates? 


\section{THEORETICAL FRAMEWORK}

Language teaching practice helps students find the link between theory and practice gap. Students at the English Language Education Study Program will experience two kinds of teaching practice: campusbased practice teaching and school-based practice teaching. Campus-based teaching gives students more opportunities to observe and experience teaching with their lecturers. It is done before they face challenges in real schools. They can focus on giving an introduction, delivering lessons, and close the lessons. Secondly, they can learn from the feedback given by their peers who act as students. Students are also able to observe real schools, make lesson plans and teach in the real class.

Studies about Indonesian pre-service teachers' beliefs have been extensively documented. In Indonesian context, Kuswandono (2013) elaborated on pre-service teachers' beliefs from their reflections. He explored how teacher candidates negotiate meaning based on learning as well as teaching experience from reflective practice. He argued that teacher candidates are "...complex and multidimensional, stemming from their different motivations for studying teaching" (p. xiv). Astika (2014) investigated how pre-service teachers were concerned with the contextual aspect of their teaching. He explained how pre-service teachers consider the importance of contextual aspects in teaching. One contextual aspect which should be considered by EFL teacher candidates is that they are going to teach digital natives. It is important for EFL teacher candidates to experience different theories and practical experience in using the new technologies. Accordingly, this study is interested in investigating the implementation of flipped learning and how it affects their engagement in the classroom.

\section{Computer Assisted Language Learning (CALL)}

Computer-assisted language learning (CALL) is the area of language learning and computers. Computers have helped the process of teaching and learning language. Another name for this area is TELL or Technology Enhanced Language Learning which focuses on different kinds of technology including phones and mobile phones (Wulandari \& Pasaribu, 2020). Technical tools are extensively believed to have strengthened language teaching. The process of teaching four language skills can be integrated with technology, for example the use of blogs to improve students' writing skills (Pasaribu, 2016), infographics to enhance students reading comprehension, podcasts to foster students listening skills, and vlogs to improve students' speaking skills (Wulandari, 2019).

The use of technology in an Indonesian context fosters learner autonomy, reduces anxiety, and improves critical thinking skills (Pasaribu, 2016; Pasaribu \& Iswandari, 2019; Prasetyawati \& Ardi, 2018; Wulandari, 2017). Seeing the advantages of using technology in the classroom, EFL teacher candidates in the English Language Education Study Program are strongly encouraged to take CALL, a course offered for the English Language Education Study Program. This program aims at providing students with the theoretical ground for using innovations in language teaching.

This study aimed at describing materials in a mobile-assisted flipped classroom for CALL. It is vital that EFL teacher candidates have rich exposure in using digital tools in the workshops throughout the semesters. Not only do students learn the theoretical grounds for integrating technology in the classroom, but students also integrate the technology in teaching practice.

\section{Flipped Classroom}

A flipped classroom model aims at encouraging students' preparation before the class and students' active engagement in the class. As the name suggests, it is a flipped version of the conventional classrooms. This learning model is defined as "the typical activities of classroom lectures followed by homework in traditional teaching procedures are reversed in order, and often supplemented or integrated with instructional videos." (Hung, 2015, p. 1) In traditional learning procedures, usually, students listen to the lectures and bring home their homework. On the other hand, in flipped learning classrooms, students are required to study supplementary materials, watch relevant educational videos, and do the homework. It is then followed by interactive discussion in the classroom. 
On a practical basis, Cockrum (2013) explained some reasons to flip the classroom. Some of them are to improve classroom management and facilitate interactions among students with different abilities and learning preferences. Jarvis et al. (2014) proposed that this model can foster student engagement in learning. Students can study the materials individually and engage actively in class discussion. In a flipped learning environment, the teachers can provide more opportunities for students to participate in active engagement. In this digital era, language teachers can design and develop flipped classrooms using various technical media.

Using mobile phones in classrooms is not new in the teaching and learning process (Ardi, 2017; KukulskaHulme \& Viberg, 2018; Reychav, Dunaway, \& Kobayashi, 2015; Sung, Chang, \& Yang, 2015). Sung, Chang, and Yang (2015) discussed that mobile-device-assisted learning has some properties beneficial for learners, namely mobility, interactivity, context-sensitivity, and individuality. Reychav, Dunaway, and Kobayashi (2015, p. 148) express how mobile learning affects "learning outside the classroom individually or collaboratively in both countries". Kukulska-Hulme and Viberg (2018) emphasized the affordances of using mobile in language learning, which promotes social constructivism. In an Indonesian context, Ardi (2017, p. 55) discussed how mobile-assisted language learning through Schoology helps students control their "learning management, cognitive process, and selection of learning materials". When they are integrated in mobile technology, students can learn language autonomously (Ardi, 2017). The mobile-assisted flipped classroom in this study utilized a Moodle 3.6 format which is responsive to mobile phones. Students can get the notification and easily log in to the course to join the discussions and online activities through their gadgets. It is then urgent to describe how a mobile-assisted flipped model is implemented in the classroom and how they foster EFL teacher candidate engagement.

\section{Student Engagement}

Student engagement can be generally classified into three dimensions: emotional or affective engagement, cognitive engagement, and behavioral engagement (Fredricks et al., 2004). However other literature suggests that social engagement and reflective engagement also play roles in the learning process. As the name suggests, emotional engagement involves students' reactions towards their classmates, teachers, academics, and schools (Fredricks et al., 2004). How students actively engage in the classroom influences their motivation in the learning process. Behavioral engagement involves students' participation such as asking questions and participating in the discussion. It is related to their habit in the class and outside the class. Social engagement deals with students' relationships with other students, such as group work or group discussion. Cognitive engagement talks about the students' scholastic success. It involves their grit in facing and solving problems (Fredricks et al., 2004). It also involves students' relationships with their teachers in the learning process. Reflective engagement is related to their reflection after engaging in a lesson. Reflective practice is considered an integral part of learning in the Ignatian Institution (Harendita, Kristiyani, Melissa, \& Julie, 2019). Students are encouraged to associate their context, the learning experience, and how to apply the knowledge in real life. They are aware of their learning goals and the progress of achieving the goals.

Some studies have linked the relationship between technology and student engagement. In flipped mathematical classrooms, Steen-Utheim and Njål Foldne (2018) showed how "affective dimension of student engagement is particularly prominent when students reflect upon learning in the flipped classroom". Lee and Walace (2018b) also highlighted the benefits of flipped classrooms for the students. They enjoy learning English and are more engaged in the learning process than the students in the non-flipped classroom. These studies indicate that flipped classrooms engage students' active learning.

However, more investigation should be reported on how flipped classrooms engage Indonesian EFL teacher candidates and prepare them to be tech-savvy when they teach in the classroom. Therefore, this study aimed at investigating the implementation of flipped learning in CALL and how it engages the EFL teacher candidates in learning and implementing digital tools in the workshop. 


\section{METHODS}

This research aimed at elaborating on how the implementation of mobile-assisted flipped classroom engaged EFL teacher candidates. With this goal in mind, we employed a case study design aiming at giving a holistic description of a case (Ary, Jacobs, \& Sorensen, 2010, p. 454). Further Hood (2009, p. 72) pointed out that a case study is "a bounded system consisting of an individual or entity and the context in which social action occurs". We employed a case study as we intended to elaborate on a holistic description of a class as a social community of learners who experienced flipped classrooms in the teacher preparation study program. Furthermore, Davies (2011) mentioned that a good case study uses different research tools to ensure validity. Accordingly, this study collected both quantitative and qualitative data to: (1) explore how web technology in a mobile-assisted flipped classroom was implemented to lead to EFL teacher candidates' engagement in learning, and (2) explain how mobile-assisted flipped classroom is linked to EFL teacher candidates' engagement. To get a holistic view of the study and ensure its validity, we used different data collection procedures, including questionnaires, interviews, and online archives.

\section{Participants}

The participants who are involved in this study are EFL teacher candidates who were students of Computer Assisted Language Learning course at Sanata Dharma University. CALL is a 16-week course with 14 meetings for content delivery and 2 meetings for a mid-term test and a final test. Upon completing this course, students are expected to be able to plan and implement quality lessons using technology to support curriculum objectives in the 21st century. It involved 34 participants, 15 male students and 19 female students, who are in the 5th and 6th semesters of their undergraduate education. As seen in Figure 1, the mobile-assisted classroom used Moodle 3.6 which is responsive to mobile phones through the Moodle app and browsers.

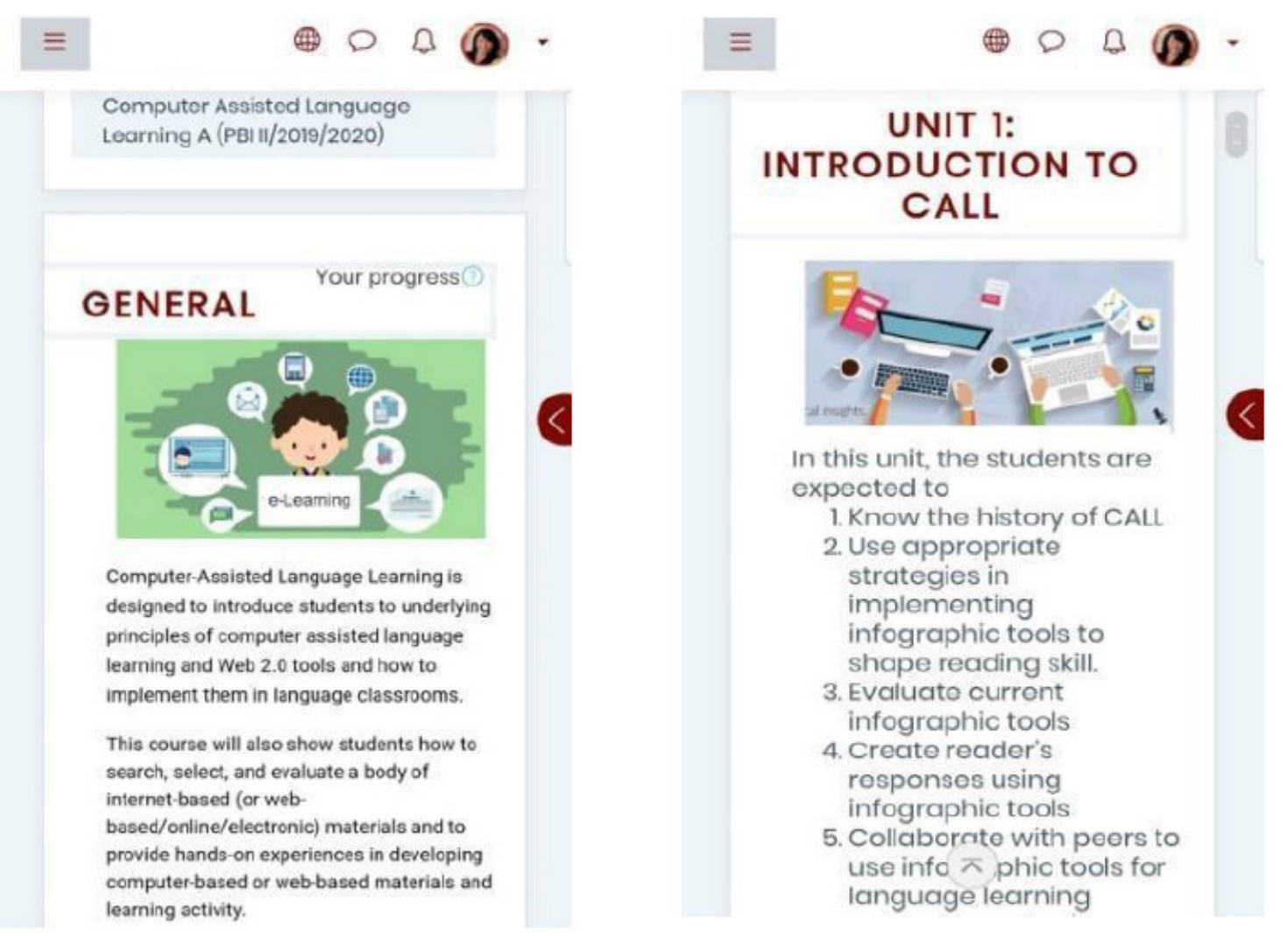

Figure 1. Screenshots of mobile-assisted CALL class 
Before conducting the research, we obtained permission from the chair of the study program. We received 29 questionnaires and invited 4 students to join the Focus Group Discussion.

\section{Data Collection and Analysis}

This study includes different kinds of instruments to collect different kinds of data to increase the validity of this case study, namely online archives, observations, questionnaires, and Focus Group Discussion (FGD). First, to describe the implementation of flipped learning in CALL, the researchers explored the instructional goals by analyzing the online archives, students' reflections, and the researchers' observations. Secondly, to elaborate on the link between a mobile-assisted flipped classroom and EFL teacher candidates' engagement, the study distributed questionnaires which were developed from library study (Fredricks et al., 2004; SteenUtheim \& Foldnes, 2018) and reviewed by the board of reviewers of Research and Community Service at a private university.

Besides collecting data from questionnaires from 29 participants, we conducted an FGD on 13 June 2019 by inviting 4 students, two of whom with high levels of engagement and the other two with low levels of engagement. First, we describe the means of the survey data to see the dimensions of engagement. We scrutinized the recording of the FGD. As we examined the data carefully, we identified the themes that can be categorized within a comprehensive theory of engagement (Fredricks et al., 2004; Steen-Utheim \& Foldnes, 2018). The data were, afterward, translated to English and deductively classified based on the categories of engagement (CE: Cognitive Engagement, BE: Behavioral engagement, EE: Emotional Engagement, SE: Social Engagement and RE: Reflective Engagement) and the source (R1: respondent 1; R2: respondent 2; R3: respondent 3; R4: respondent 4). Multiple sources of data were triangulated to improve the reliability of the study. In a case study, data from different sources are used to mitigate bias (Fusch, Fusch, and Ness, 2018). They further stated that, "Enhancing the validity of the study results through triangulation ensures that one's research is worthy of a contribution to the existing body of knowledge" (p. 29). The findings from the current study were also compared with those of relevant research to get a holistic view of the learners' engagement in a mobile-assisted flipped classroom.

\section{FINDINGS AND DISCUSSION}

To answer the first research question, the researcher observed the class and took notes on how a mobileassisted flipped learning model is implemented in the class. This study described the instructional goals and the materials given in the class learning cycles.

\section{Flipping the class}

Flipped learning was conducted in two environments, namely outside and inside the classroom. There must be detailed planning to make sure that learning in both environments were perfectly integrated (Basal, 2015). This section discusses the teacher's role and students' activities in the implementation of a mobileassisted flipped classroom.

\section{Teacher's Roles}

The teacher took the role of the material developer or curator. The teacher designed and developed the materials and activities using various technical media. Using technology in classrooms is not new in the teaching and learning process. Technical tools such as vlogs, videos, blogs, news websites help EFL students to acquire and master four language skills. The mobile-assisted flipped classroom utilized a Moodle 3.6 format which is responsive to mobile phones. Students can get a notification by logging in to the course to join the discussions and online activities.

Because a flipped classroom model requires students to study materials available on the website, watch relevant educational videos, and do the homework, the materials should be ready at the beginning of the semester. The teacher in this CALL class compiled the drafts of the materials before the cycle of the flipped 
class. Each unit contains concepts of language learning and practical applications to teach a foreign language. Each unit was explored in two meetings. Table 1 elaborates on the outline of the materials and activities uploaded in mobile-based Moodle.

Table 1. Materials in mobile-assisted CALL class

\begin{tabular}{|c|c|c|c|c|c|c|}
\hline \multirow[t]{2}{*}{ UNIT } & \multirow[t]{2}{*}{ CONTEXT } & \multirow[t]{2}{*}{ EXPLORE } & \multicolumn{2}{|l|}{ LINK } & \multirow[t]{2}{*}{ PRACTICE } & \multirow[t]{2}{*}{ APPLY } \\
\hline & & & WORKSHOP & $\begin{array}{l}\text { TARGETED- } \\
\text { SKILLS }\end{array}$ & & \\
\hline UNIT 1 & History of TELL & $\begin{array}{l}\text { History of CALL \& } \\
\text { criteria of a good } \\
\text { app }\end{array}$ & $\begin{array}{l}\text { Canva \& } \\
\text { Infographic }\end{array}$ & Reading & $\begin{array}{l}\text { Creating an } \\
\text { infographic }\end{array}$ & $\begin{array}{l}\text { Making a lesson } \\
\text { plan }\end{array}$ \\
\hline UNIT 2 & Digital Literacy & $\begin{array}{l}\text { Digital Immigrant } \\
\text { vs. Digital Natives }\end{array}$ & $\begin{array}{l}\text { Youtube, } \\
\text { EdPuzzle, and } \\
\text { Discussion } \\
\text { Forum }\end{array}$ & Listening & $\begin{array}{l}\text { Creating video } \\
\text { blog }\end{array}$ & $\begin{array}{l}\text { Choosing the right } \\
\text { video }\end{array}$ \\
\hline UNIT 3 & Gamification & Gamification & $\begin{array}{l}\text { Quizizz, } \\
\text { Kahoot }\end{array}$ & $\begin{array}{l}\text { Grammar and } \\
\text { Vocabulary }\end{array}$ & $\begin{array}{l}\text { Creating an } \\
\text { online quiz } \\
\text { using Quizizz }\end{array}$ & $\begin{array}{l}\text { Creating language } \\
\text { game using } \\
\text { Wordwall }\end{array}$ \\
\hline UNIT 4 & $\begin{array}{l}\text { Collaborative } \\
\text { activities }\end{array}$ & $\begin{array}{l}\text { Collaborative } \\
\text { activities }\end{array}$ & $\begin{array}{l}\text { Google docs, } \\
\text { form, and } \\
\text { drive }\end{array}$ & Writing & $\begin{array}{l}\text { Collecting data } \\
\text { using google } \\
\text { form }\end{array}$ & $\begin{array}{l}\text { Designing } \\
\text { collaborative } \\
\text { activities using } \\
\text { GAFE }\end{array}$ \\
\hline UNIT 5 & $\begin{array}{l}\text { Mobile } \\
\text { Learning }\end{array}$ & MALL & $\begin{array}{l}\text { Skype and } \\
\text { chatroom }\end{array}$ & Speaking & $\begin{array}{l}\text { Having a video } \\
\text { conference }\end{array}$ & $\begin{array}{l}\text { Screencasting / } \\
\text { Vlogging }\end{array}$ \\
\hline UNIT 6 & $\begin{array}{l}\text { Learning } \\
\text { Management } \\
\text { System / } \\
\text { Developing } \\
\text { e-learning }\end{array}$ & Blended learning & $\begin{array}{l}\text { Edmodo } \\
\text { and Google } \\
\text { Classroom }\end{array}$ & All skills & Exploring LMS & $\begin{array}{l}\text { Planning a flipped } \\
\text { learning }\end{array}$ \\
\hline
\end{tabular}

As seen in Table 1, the course is both theoretical and practical in nature. The materials in this mobile-based flipped classroom course are divided into 5 sections, namely 1) Context, 2) Explore, 3) Link, 4) Practice, and 5) Apply. The first section, Context, helps students activate their background knowledge related to the material. This section emphasizes how students use previous experiences to interpret and learn from the theory. Students' interpretation of the material can be derived through the context of their past knowledge, known as the "schema." Activating schema is essential to conduct an effective learning process. The second section is Explore which elaborates on pedagogical concepts applied in the area of Computer-Assisted Language Learning. Students are introduced to some relevant theories such as the history of CALL, digital literacy, gamification, mobile-assisted language learning and Learning Management System. The next section, Link, is practical in nature. This section presents information on how to implement the EdTech tool in the language classroom. Practice section is a project-based task where students can apply their knowledge to produce digital content for teaching English. Finally, the section Apply accommodates practice for planning their language classes. Due to their role as pre-service teachers, they need to be able to design lesson plans which integrate language learning and digital content/media.

Additionally, there are two extra sections to help the students reflect on their learning, namely Evaluate and Self-Assess. The section Evaluate guides students to explore some new digital tools which are not mentioned in the LMS and decide if the tool meets the requirements of good learning apps. Technology develops rapidly, and the only constant part is change. Accordingly, we need to prepare our students to encounter this constant change by guiding them in choosing new apps appropriate for EFL learning. Lastly, the section Self-Assess helps them reflect independently on their understanding and check their understanding of the materials learned. 


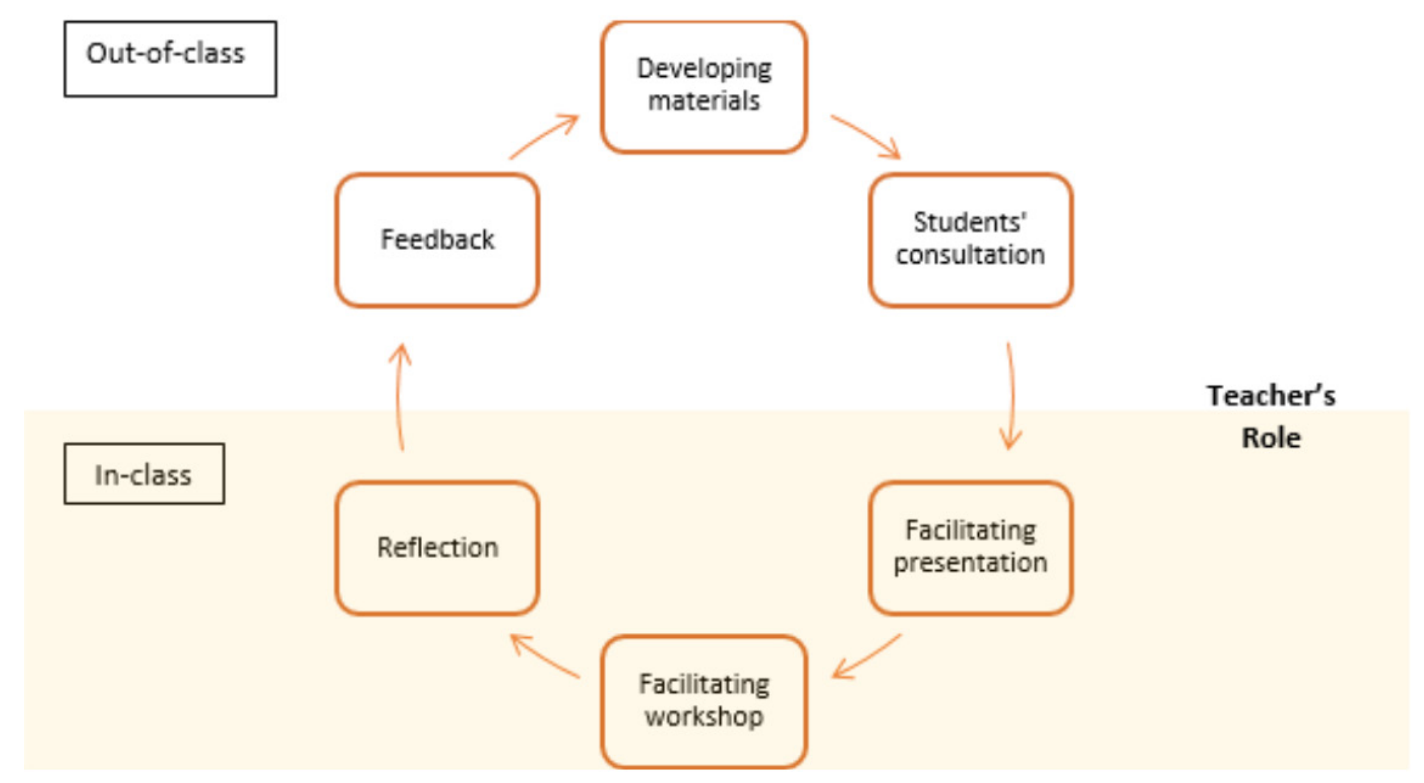

Figure 2. Teacher's role in the mobile-assisted flipped classroom

As seen in Figure 2, besides developing the material in the mobile-based flipped classroom, the teacher provided consultation sessions to avoid misconceptions during the presentations and workshops. This consultation time was essential to ensure that the groups were well prepared in presenting the material to their peers. The teacher's role, therefore, was shifted from "sage on the stage" to "guide on the side" (Gillies, 2006). Teachers are not seen as the main source of knowledge in the class. Students are empowered through this allotted consultation time.

In a mobile-assisted flipped classroom, the teacher also took a role as a facilitator in students' presentations, workshops, and reflection. As a facilitator, first, she gave responsibilities to the students to do the tasks individually and in groups. Secondly, the teacher offers support and advice when the students face challenges in doing the tasks in the workshops. The teacher also helps students evaluate and monitor their learning in the class through reflection. She helps the students achieve the learning goals by being a facilitator.

The teacher helps students monitor their progress by giving feedback and also encouraging peer feedback. Teachers need to ensure that both learnings (outside and inside the classroom) are integrated effectively. Therefore, thorough feedback was needed to check whether the expected goals of learning were achieved by students. Feedbacks were given to both the presentations and projects.

\section{Students' Activities in A Mobile-Assisted Flipped Classroom}

With the materials ready in Moodle, the students were expected to read or review the materials before the class. However, difficulties may occur when the students do not do their responsibilities by accessing the materials prior to class activities (Bristol, 2014; Kordyban \& Kinash, 2013). Therefore, we allotted consultation time before the group presentation. Students worked in a group of three students to create digital teaching media and deliver presentations. The class activities are group presentations, quizzes, discussions, and digital tools for teaching workshops. Finally, after-class activities are tasks/project submissions, reflections, and evaluations.

The students are grouped into 12 groups with random topics for the semester. This presentation is collaborative in nature, so the students work in groups. A great deal of literature suggests the benefits of collaboration. Coates (2006) highlighted the importance of collaborative learning for classroom engagement. The students worked together with their peers in preparing the presentations. They shared different responsibilities. In the classroom, students also felt less tense when listening to their peer presentations and asking questions to the presenters.

In the pre-study stage, the students consulted their presentation draft to the teacher before their presentation. They revised the drafts by adding or deleting some information and rearranging the order of the presentations. The teacher advised the students to interact with the audience as seen in Figure 3. 


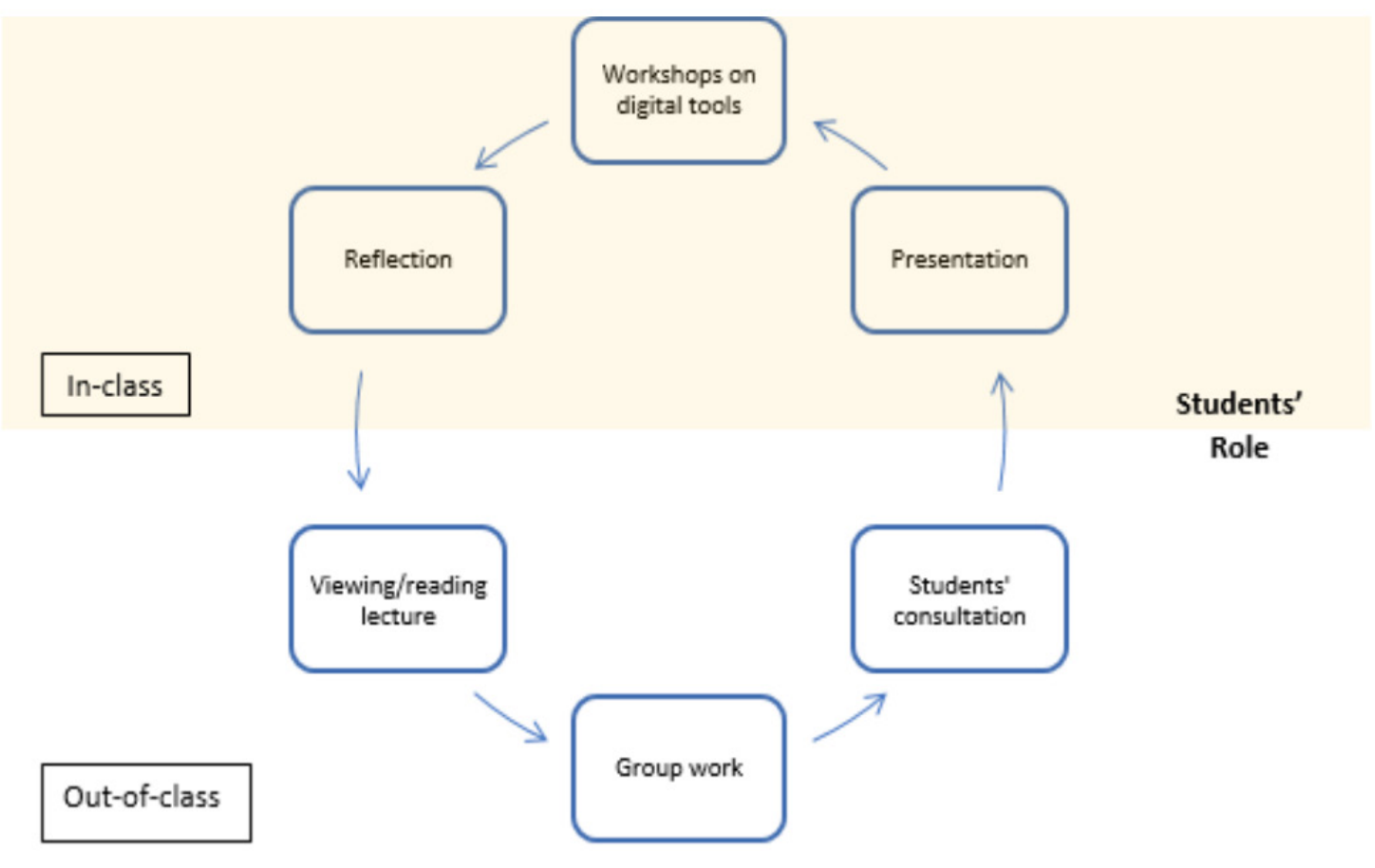

Figure 3. Students' role in the mobile-assisted flipped classroom

In the class, the students presented the theories and digital tools' implementation. Both the lecturer and students participated actively. As seen in Figure 3, after the presentations, the students executed the tasks where the students practice and apply the knowledge gained in groups. The class is ended by reflecting and evaluating the presenters' performance. Students are also encouraged to write reflections to gain an in-depth understanding of the materials and connect them with their context as seen in these students' reflections as EFL teacher candidates:

I agree that the games can motivate students in learning something. It is because students need the variation of learning. They prefer to learn while playing games rather than just reading the books and doing the exercises. The materials will be accepted easily if students like the things they do.

(Reflection 1)

A part that I want to know more is Gamification Apps for Enhancing and Motivating ESL Learning. As a future teacher I want to know what games that can be used as the media in my teaching activity in the classroom. I have to be aware about the straights and weaknesses of some games in order to prevent some negative effects on my future students.

\section{(Reflection 2)}

Students' reflections 1 and 2 demonstrate that the students were aware of the benefits of gamification and learning (Reflection 1) and eager to know more on the topic (Reflection 2). Additionally, they also monitored their friends' performance by completing an evaluation survey administered by using Google Form. They were asked to give their responses on the texts uploaded in the mobile-assisted flipped classroom.

The students were asked to develop various digital media in the presentations or workshops for different language skills (reading, writing, listening, and speaking) and language components (vocabulary and grammar). They developed language learning media by using Canva (for reading), eDpuzzle (for listening), GAFE (for writing), Instagram Vlog or screencast for speaking and Quzizz for vocabulary and grammar. They also made a Google site where they combined their portfolio. One sample of the students' portfolio can be seen in Figure 4 (URL: https://sites.google.com/view/lourdesworkshop/beranda ). 


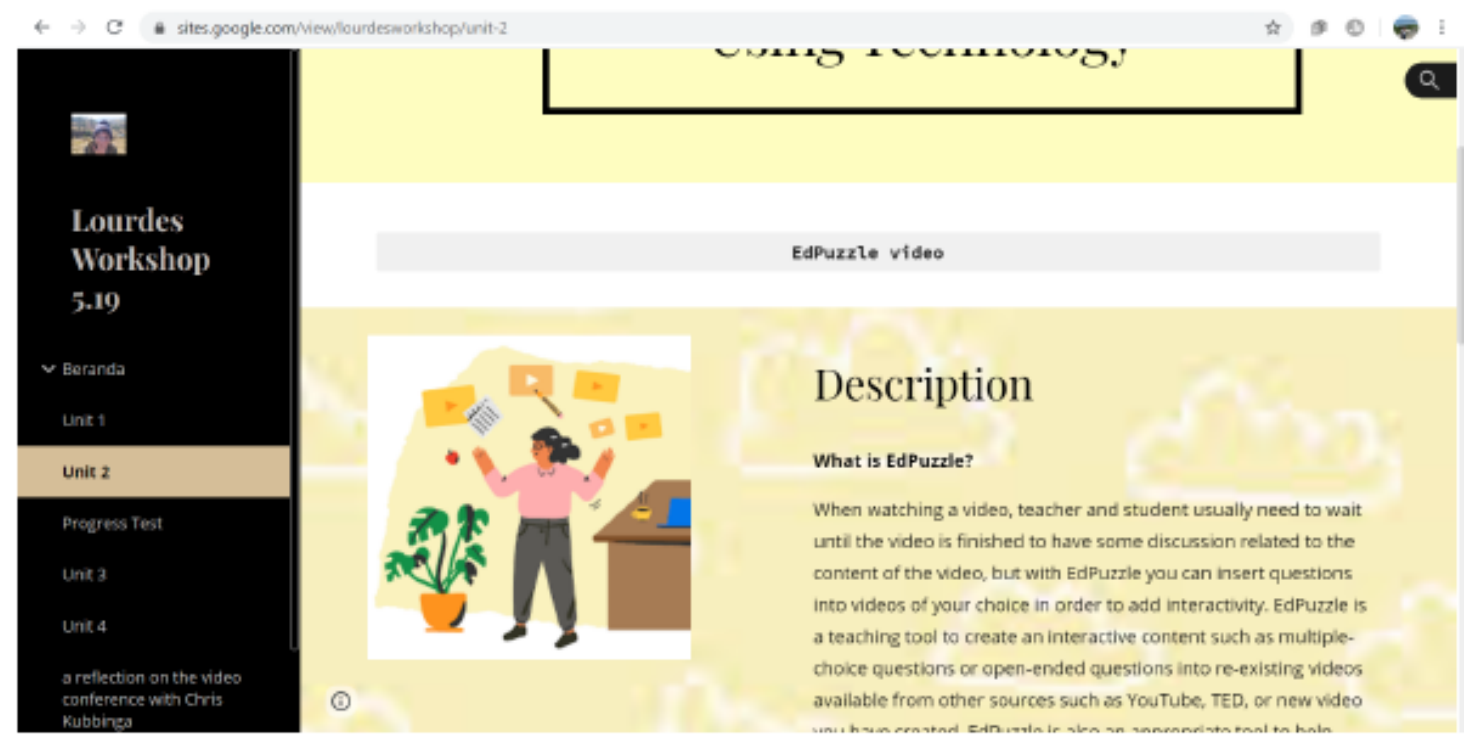

Figure 4. An example of a student portfolio

Figure 4 is a portfolio of different kinds of digital tools for language teaching compiled by the student. In this portfolio, they presented various digital media in the presentations or workshops for different language skills (reading, writing, listening, and speaking) and language components (vocabulary and grammar).

\section{Flipping the Class}

To answer the question of the research, the researcher developed questionnaires based on different domains of engagement (Fredricks et al., 2004; Steen-Utheim \& Foldnes, 2018). Furthermore, the researcher conducted an FGD with four students, who were selected based on their observed engagement in the class. In the FGD, the participants revealed the possible connections between a flipped learning model and their engagement as well as how it prepares them to use technology in teaching.

The data from the questionnaire show that the students have positive engagement in the flipped classroom $(M=3.98)$. Their engagement in the class can be broken down into several types of engagement as seen in Table 2 .

Table 2. Types of EFL teachers' engagement

\begin{tabular}{ll}
\hline Types of Engagement & Means \\
\hline Emotional engagement & 4.1 \\
Behavioral engagement & 3.9 \\
Cognitive engagement & 4.2 \\
Reflective engagement & 4.0 \\
Social engagement & 3.5 \\
\hline
\end{tabular}

The data show that the students experience five aspects of engagement. Table 2 shows that students are engaged cognitively $(M=4.3)$. The possible interpretation is that students are able to achieve the learning goals by being able to integrate technology in teaching practice. The next one was emotional engagement $(M=4.1)$. Students were motivated to use technology in the classroom. The reflective engagement is also positive $(M=4.0)$ as students were aware of the importance of using technology. Students also show positive social engagement and behavioral engagement.

Emotional engagement involves students' reactions towards their classmates, teachers, academics, and schools (Fredricks et al., 2004). How students actively engage in the classroom influences their motivation in the learning process. Table 3 summarizes students' emotional engagement through the following statements: 
Table 3. Emotional engagement

\begin{tabular}{lll}
\hline No & Statements (S) & Means \\
\hline 1 & I enjoy using technology for teaching and learning English in the classroom. & 4.5 \\
2 & I am confident to use technology for teaching and learning in the class. & 4.1 \\
3 & I avoid using technology for teaching and learning English. & $3.9^{*}$ \\
4 & I am excited to discover digital tools for teaching and learning English. & 4.4 \\
5 & I am anxious (afraid) to use technology for my projects after the class. & $3.6^{*}$ \\
\hline
\end{tabular}

Table 3 shows that students tend to engage emotionally (average mean=4.1). They enjoy (S1), feel confident (S2), and excited (S3) to use technology. The inverted statements (S2 and S5) show inverted scores. From the mean score, students did not avoid and were not anxious about using technology. Academic engagement empowers students to develop greater students' well-being (Pietarinen, Soini, \& Pyhalto, 2014). Having engagement, the students were motivated in participating in the class as seen in the FGD. The data from the FGD demonstrate that students are positive in experiencing mobile-assisted flipped classroom, as seen in F1 (FGD Data 1) to F6.

1. [The CALL class is] ... exciting because the teacher asked us to read [the materials], but I did that some minutes before. (FGD_R3)

2. I like the presentation variation. When we have a presentation we talk about the class' materials. But when we have workshop, we make something new that can be applied [in class] (FGD_R4)

3. I feel comfortable because I must prepare the presentation. (FGD_R4)

4. I felt anxious when presenting the materials. But after presenting, I felt glad. I felt ready, because I have understood. (FGD_R1)

5. I enjoy using the browser, because I am used to using the old version of Moodle. (FGD_R2)

6. I enjoy that this week is presentation [of the theory] and next week is the workshop. After learning the knowledge, we applied it in workshop. We learnt to link the language skills and the tools. (FGD_R4)

The adjectives in the data, namely exciting, like, comfortable, glad, and enjoy in the data demonstrate positive feelings toward the class, the activities, and the tools. Students' statements show that the emotional dimension of engagement leads to enjoyment (Daniels, Adams, \& Mccaffrey, 2016) and motivation (Fredricks et al., 2004). Flipping the class enabled them to be more prepared in the class since they knew what they would learn in the lesson.

Daniels, Adams, and McCaffrey (Daniels et al., 2016) also suggest that engagement leads to more effort, which is considered in the behavioral domain of engagement. Behavioral engagement includes students' participation such as asking questions and participating in the discussion (Fredricks et al., 2004). It is related to their habit in the class and outside the class. Research also included persistence and focus on academic tasks (Cooper, 2014; Yazzie-Mintz \& McCormick, 2012). The following values from the questionnaire show EFL teacher candidates' behavioral engagement.

Table 4. Behavioral engagement

\begin{tabular}{lll}
\hline No & Statements $(S)$ & Means \\
\hline 6 & I preview the materials before the class. & 3.2 \\
7 & I discuss the materials with my friends and lecturer. & 3.8 \\
8 & I am attentive to my teachers' instructions. & 4.1 \\
9 & I do the projects by applying the knowledge obtained in the class. & 4.0 \\
10 & I access the materials although it costs me my phone Internet data. & 4.4 \\
\hline
\end{tabular}

Although the overall score in the data is positive (mean=3.9), the findings show that some students were not accustomed to preparing the materials before the class ( $\mathrm{S} 10$, mean=3.2). However, Table 4 shows that students 
tend to engage by discussing the materials, being attentive to the instructions, doing the projects, and accessing the online materials for the class. The data confirmed that students participate in class activities (Cooper, 2014; Yazzie-Mintz \& McCormick, 2012). The FGD shows how they participated in and outside the class.

7. Engaging and new because I think flipped [classroom] is ideal. Since High School we were taught without a textbook, so we learnt without preparation. In this course, we have the materials, so we can read. If we were absent we could read the materials by ourselves. (FGD_R4)

8. I accessed the site 30 minutes before the class. (FGD_R3)

9. [the materials] are varied because we can read and listen to the presentations. (FGD_R4)

10.I read [the materials] the night before so I can make some connections with the presentation. I am sure that the information is more complete in the reading materials. (FGD_R4)

From the text in bold, it was revealed that the students show behavioral engagement in terms of reading the materials outside the class in advance of class meetings (Basal, 2015; Webb, Doman, \& Pusey, 2014; Wulandari, 2017). F7 suggests that the students think being able to prepare for the materials before the class is ideal. She also added that students can still follow the materials when they were not able to attend the class on a particular day. From F8 and F9, it was found that students exhibited behavioral engagement by both reading the materials and listening to their friends' presentations. Although some students did not preview the materials, they engaged with the lessons by listening to their friends' presentations.

Cognitive engagement talks about the students' scholastic success as it involves their grit in facing and solving problems (Fredricks et al., 2004). It shows how students invest their time and energy to gain certain skills and knowledge. The participants show their cognitive engagement through the following statements:

Table 5. Cognitive engagement

\begin{tabular}{llc}
\hline No & Statements (S) & Means \\
\hline 11 & I can integrate digital tools in the lesson plan. & 4.1 \\
12 & I can assess the use of digital media for learning. & 4.3 \\
13 & I understand how to utilize technology in teaching practice. & 4.0 \\
14 & I realize that the knowledge of technology and teaching language skills will be useful for my teaching & 4.7 \\
& career in the future. & 4.1 \\
\hline
\end{tabular}

The students experienced cognitive engagement as seen from the average means of this variable (mean=4.2). They gained the knowledge to integrate digital tools in lesson plans (S11), the skills to assess digital tools for learning (S12), and skills to integrate digital media in the lesson plan (S13). This cognitive ability is required by the teacher to teach digital natives (Wulandari \& Pasaribu, 2020). They are also aware of these skills and knowledge in the class (S14 and S15). The FGD confirmed these statements.

11.I'm so familiar with the techs to help us teach. I wrote a final paper about technology. (FGD_R1)

12.I use technology in my tutor class. They are excited. (FGD_R3)

13.After CALL class, I could make a quiz. (FGD_R3)

14. The class helps me evaluate the learning materials, like the use of the application with statistics to know the development of our students. (FGD_R1)

Daniels et al. (2016) mentioned that cognitive engagement includes the "investment put into thinking about their tasks". The data from the discussion confirmed that the students understood how technology helped them in teaching (F11), implemented digital tools when teaching (F12 and F13), and evaluated the online materials (F15). The students exercise their thinking skills by understanding, applying, and evaluating the tools learned in class.

Furthermore, students also reflect their reflective engagement as it is an integral part of learning in an Ignatian institution. We collected the data from an Ignatian university which put a high value on reflections. Harendita et al. (2019) highlighted that "reflection is an attempt to understand more deeply what has been 
learned. Educators lay the foundations for learning how to learn through involving students in reflection skills and techniques. Students are encouraged to associate their context, the learning experience, and how to apply the knowledge in real life". The data in the study show that the students were aware of their learning goals and the progress of achieving the goals. The participants show their reflective engagement through the following statements. The following values from the questionnaire show their behavioral engagement.

Table 6. Reflective engagement

\begin{tabular}{lll}
\hline No & Statements (S) & Means \\
\hline 16 & I monitor my own progress through feedback and grades from the lecturer. & 3.8 \\
17 & I am aware that I have to prepare the materials before the class. & 3.8 \\
18 & I am aware that my engagement in the class will support learning effectiveness. & 4.1 \\
19 & I am aware of the difficulties I face in the class. & 3.9 \\
20 & I am aware that the project will help me understand the materials in the future. & 4.3 \\
\hline
\end{tabular}

This study agrees with Spalding and Wilson (2002) who proposed that writing reflections engage students with the learning activities. The data from the questionnaire in Table 6 present the students' evaluation (S16) and awareness (S17, S18, S19, S20). The mobile-assisted flipped classroom is designed to enable students to reflect on the topics, materials, and activities designed.

15.I reviewed my previous projects. I reviewed them before making the portfolio. (FGD_R3)

16.I am aware of what would be discussed in CALL, I should have been more prepared to understand better. (FGD_R3)

17.I become more aware. Before I blamed my teacher when I didn't understand the materials. After all, we have the obligation to exercise independent learning. (FGD_R4)

18. The LMS has personalized feedback because we all got feedback. (FGD_R4)

This kind of engagement also emerged from the FGD. The students demonstrated reflective engagement by reviewing previous projects (F15), acknowledging the importance of preparation, being more aware of one's responsibilities (F16 and F17). This experience is possible because they get personalized feedback from the mobile-assisted platform (F18). Students were able to get feedback in the form of comments and grades on their digital media and presentation from their peers and teachers through their mobile devices.

Finally, the students also show social engagement by doing group work or group discussion. Pasaribu (2020) mentions that students show online and offline engagement which might be influenced by their belief in gotong royong or mutual cooperation. Table 7 shows that students scored the lowest in giving comments to friends' posts because they tend to go offline to ask questions and discuss the projects.

Table 7. Social engagement

\begin{tabular}{lll}
\hline No & Statements (S) & Means \\
\hline 21 & I give comments to my friends' posts. & 2.7 \\
22 & I ask questions to my friends and teachers when I face problems. & 4.0 \\
23 & I participate actively in the classroom discussion. & 3.4 \\
24 & I appreciate my friends' and my teachers' comments. & 4.5 \\
25 & I read my friends posts outside the class. & 3.4 \\
26 & I ask questions to my lecturer outside the class & 3.1 \\
\hline
\end{tabular}

Digital tools enable students to engage both offline and online through technology. However, they tend not to give comments to their friends' posts (S21) in an online environment because they prefer to have direct discussion with their friends. We can also see in the questionnaire that the students valued both their teacher 
and peers' comments (S24). The flipped classroom enables students not only to participate in the class discussion but also to read students' posts and ask teachers outside the class.

19.Learning in groups helps us to improve collaboration skills. It is useful for our future at school or the company. (FGD_R1)

20. The online group work is usually done through WA, but we discuss it directly after the class. (FGD_R4)

21.Sometimes we want to be practical, so we distribute the materials, but we only learn about our own part. Usually, there is a leader who understands the whole picture. (FGD_R4)

22. When we had our presentation for the first time, we read Moodle. Al understood the materials better, so he explained them to us. When I understand the materials better, I will explain them. So, we complete each other. (FGD_R3)

The FGD also shows how students exercise their collaboration skills (F19) through Whatsapp and offline discussion (F20). However, some also experienced social problems since not everyone is well-prepared for projects or group work (F21). But one student highlights their social engagement by saying that they help each other after reading the materials from Moodle (F22). The data confirm that flipped classrooms facilitate different kinds of media to engage socially. It aligns with an argument highlighted by Rennie (2008) that eLearning should engage learners socially. However, in this flipped classroom there is a gap between the act of giving online comments and the appreciation of receiving online comments. The act of giving online comments seems to be rated lower than the appreciation of receiving comments. This gap emerges as students tend to have direct discussion since they can receive instant responses.

This study has discussed the implementation of a mobile-assisted flipped classroom that leads to EFL teacher candidates' engagement. From the above-mentioned elaboration, we noticed that as the teacher provided different modes of learning and interactions in the mobile-assisted platform, the students demonstrated all dimensions of engagement. The discussion highlights that the implementation of the mobile-assisted flipped classroom for EFL teacher candidates in the CALL class helps them gain technological knowledge and skills then apply them in the learning environment as they choose, integrate and evaluate tools for language learning. It agrees with Gonen (2019) who found qualitatively that pre-service teachers experience the benefits of using digital tools in improving IT skills and classroom atmosphere. Teacher candidates enjoyed the contents in the mobile-assisted flipped learning as they were presented in different formats, which accommodated their learning styles and strategies. Besides, the students were able to participate actively as they applied their knowledge in different kinds of digital projects. The students were familiar with the benefits of reflective practices in the university and through the implementation of a flipped model, the students were more able to reflect on the learning materials. The teacher can also follow students' reflection directly from the online platform. Furthermore, the students can always access the materials, their progress, and the evaluation which makes them abler to monitor their progress.

However, it is important to note that not all students came to the class prepared. Some had not read or viewed the materials before the class. Reading without direct supervision from the teacher might be difficult for students who were dependent on constant direct supervision. Due to the long-established prevalence of teacher-centeredness in the Indonesian context (Masduqi, 2014), it is a challenge to make students wellprepared before the class. One way to deal with this is that the teachers need to provide a consultation time/reminder outside the class to check whether the learners were well-prepared. Teachers must encourage learners to fully maximize the available resources in flipped classrooms. Another noteworthy finding was that although the students did not rate the social engagement in the online platform as high as the emotional, behavioral, cognitive, and reflective engagement, the results of the FGD demonstrate how they valued the importance of collaborative work. They did not comment or discuss the task in the Moodle since they preferred face to face discussion or discussion through Whatsapp after the class. The learners tend to have direct meetings with the lecturer at the consultation time and discuss the tasks directly with their friends prior to the class. 


\section{CONCLUSION}

Although this study is limited in size, some findings should be highlighted. First, the mobile-assisted flipped classroom in CALL class is both theoretical and practical in nature. The teacher was responsible for providing content materials, activities, offering consultation time before the class, facilitating in-class activities, and giving feedback. The contents or theories in the form of videos, infographics, and documents materials were uploaded before the class for the students to access. The class activities and practical instructions were designed and developed using various technical media. The students were required to read the materials before the class, work in groups to complete the tasks, consulting their works, and reflecting their learning. The data from observations, questionnaires, and focus group discussion show that the flipped course leads to emotional, behavioral, cognitive, social, and emotional engagement in learning. EFL teacher candidates were given opportunities to discuss theories on educational technology and integrate digital tools in learning throughout the study. Throughout the class, they enjoyed experiencing the integration of technology in teaching and learning, which is relevant and applicable for their teaching practices. Moreover, the participants of the study underlined their cognitive engagement in understanding, applying, and evaluating the digital tools for language learning and teaching. Through the implementation of the flipped model, they were more able to exercise behavioral engagement by participating actively in the class, although the data required teachers to investigate more ways to encourage students to be more well-prepared by reading the materials before the class. They also showed reflective engagement throughout the study by monitoring their learning through feedback given personally by the lecturer. It is also evident from the data that students have the spirit of gotong royong or mutual collaboration in doing the tasks, although they prefer to communicate face to face, right after the class, rather than to communicate virtually.

Based on the above-mentioned discussion, we put forward some recommendations for teacher preparation programs. First, the programs should provide opportunities for teacher candidates to have hands-on experience in integrating technology in learning and teaching. Secondly, mobile-assisted flipped instructions are effective for teacher preparation programs as it fosters different dimensions of engagement. Thirdly, the lecturers should facilitate mobile-assisted flipped learning by providing content materials, activities, offering consultation time before the class, facilitating in-class activities, and giving personalized feedback. We also recommend that teachers develop more interactive online discussions to support their social engagement in learning. The findings of this study should be viewed within its limitations in scope. This study involved 29 EFL teacher candidates who were equipped with digital facilities, including computers and Internet access in a computer laboratory. Other research with a more diverse population could be conducted in the future to increase validity. Investigations on engagement in full online instructions in Indonesia should also be investigated further.

Acknowledgements: We would like to thank Mr. Eric for proofreading our manuscript, LPPM USD for funding the research, and two anonymous reviewers for their constructive feedback.

\section{BIODATA and CONTACT ADDRESSES of AUTHORS}

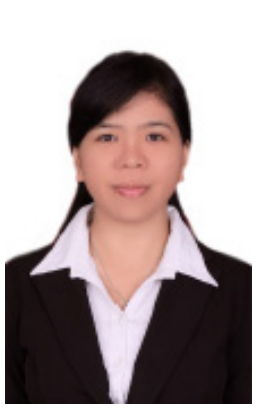

Truly Almendo PASARIBU has been teaching at English Language Education, Universitas Sanata Dharma, Yogyakarta, Indonesia since 2013. She graduated from Universitas Negeri Malang majoring in English Language and Literature and obtained her master's degree in Linguistics from Universitas Gadjah Mada in 2013. She has published several books in English language learning and technology as well as research articles in national and international journals. Her research interests include applied linguistics, sociolinguistics, and classroom discourse analysis. She is now supported by an Australian Government Research Training Program (RTP) Scholarship to pursue a doctoral degree at Monash University, Australia. 
Truly Almendo PASARIBU

English Language Education Study Program, Teachers Training and Education Faculty Address: Sanata Dharma University, Jl. Affandi, Santren, Caturtunggal, Kec. Depok,

Kabupaten Sleman, Daerah Istimewa Yogyakarta 55281, Indonesia

E-mail: trulyalmendo@usd.ac.id

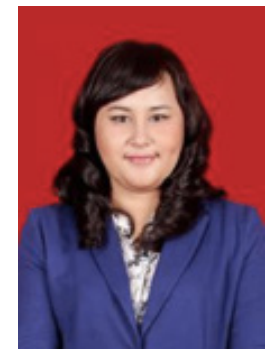

Mega WULANDARI is a lecturer of English Language Education Study Program at Teachers Training and Education Faculty, Sanata Dharma University. She gained her Master's degree in Educational Technology from English Studies, Sanata University. Her academic interests include language teaching media, educational technology, e-learning, and English material design. She has authored 2 books, some articles published in national and international indexed journals, and papers submitted to international conferences.

\section{Mega WULANDARI}

English Language Education Study Program, Teachers Training and Education Faculty Address: Sanata Dharma University, Jl. Affandi, Santren, Caturtunggal, Kec. Depok, Kabupaten Sleman, Daerah Istimewa Yogyakarta 55281, Indonesia

Phone: +62 82226862244,

E-mail: mega@usd.ac.id

\section{REFERENCES}

Ardi, P. (2017). Promoting learner autonomy through schoology M-Learning platform in an EAP class at an Indonesian University. Teaching English with Technology, 17(2), 55-76.

Ary, D., Jacobs, L. C., Sorensen, C. K. (2010). Introduction to Research in Education (8th ed.). Belmont: Wadsworth.

Astika, G. (2014). Reflective teaching as alternative assessment in teacher education: a case study of preservice teachers. TEFLIN Journal, 25(1), 16-32.

Basal, A. (2015). The implementation of a flipped classroom in foreign language teaching. Turkish Online Journal of Distance Education, 16(4), 28-37.

Bristol, T. J. (2014). Educate, excite, engage. Teaching and Learning in Nursing, 9, 43-46, Retrieved from September 23, 2019 from https://doi.org/10.1016/j.teln.2013.11.002

Cakir, H. (2013). Use of blogs in pre-service teacher education to improve student engagement. Computers and Education, 68, 244-252. Retrieved from March 29, 2020 from https://doi.org/10.1016/j. compedu.2013.05.013

Chen Hsieh, J. S., Wu, W. C. V., \& Marek, M. W. (2017). Using the flipped classroom to enhance EFL learning. Computer Assisted Language Learning, 30(1-2), 1-21. https://doi.org/10.1080/095882 21.2015.1111910

Coates, H. (2006). Student Engagement in Campus-Based and Online Education: University Connections. Melbourne Routledge Taylor \& Francis

Cockrum, T. (2014). Flipping Your English Class to Reach All Learners: Strategies and Lesson Plans. New York: Routledge.

Demski,Cooper, K. S. (2014). Eliciting engagement in the high school classroom: a mixed-methods examination of teaching practices. American Educational Research Journal. Retrieved from September 23, 2019 from https://doi.org/10.3102/0002831213507973

Daniels, L. M., Adams, C., \& Mccaffrey, A. (2016). Emotional and social engagement in a massive open online course: an examination of Dino 101. In Emotions, Technology, and Learning. Retrieved from September 23, 2019 from https://doi.org/10.1016/B978-0-12-800649-8.00004-3

Danker, B. (2015). Using flipped classroom approach to explore deep learning in large classrooms. The IAFOR Journal of Education, III(I), 171-186. 
Davies, M. (2011). Study Skills for International Postgraduates. In Study Skills for International Postgraduates. Retrieved from June 2, 2019 from https://doi.org/10.1007/978-0-230-34553-9

Davies, R. S., Dean, D. L., \& Ball, N. (2013). Flipping the classroom and instructional technology integration in a college-level information systems spreadsheet course. Educational Technology Research and Development, 61(4), 563-580.

Franklin, T. (2011). Mobile learning: at the tipping point. Turkish Online Journal of Educational Technology, 10 (4), 261-275

Fredricks, J. A., Blumenfeld, P. C., \& Paris, A. H. (2004). School engagement: potential of the concept, state of the evidence. Review of Educational Research, 74, 59-109.

Fusch, P., Fusch, G.E. \& Ness, L.R. (2018). Denzin's paradigm shift: revisiting triangulation in qualitative research. Journal of Social Change 10(1), 19-32

Gilbert, J. (2013). A collaborative online reading and research project. In Blended Learning in English Language Teaching: Course Design and Implementation. 27-34 https://doi.org/10.1002/tesq.215

Gillies, R. M. (2006). Teachers' and students' verbal behaviours during cooperative and small group learning. British Journal of Educational Psychology, 76(2), 271-287.

Giron-Garcia, C. (2015). Literacy and technologies in EFL Settings: fostering reading comprehension on the Internet. Bellaterra Journal of Teaching \& Learning Language \& Literature, 8(2), 39-50.

Gonen, S. I. K. (2019). A qualitative study on a situated experience of technology integration: reflections from pre-service teachers and students. Computer Assisted Language Learning, 32(3), 163-189. https://doi.org/10.1080/09588221.2018.1552974

Harendita, M. E. (2013). Why resist?: a closer look at Indonesian teachers' resistance to ICT. International Journal of Indonesian Studies, 1(2), 79-109.

Harendita, M. E., Kristiyani, T., Melissa, M. M., \& Julie, H. (2019). The implementation of Ignatian Pedagogy in a Jesuit University in Indonesia: students' perspectives. Jesuit Higher Education: A Journal, 8(2), 59-67

Harris, J., Koehler, M., Koehler, M. J., \& Mishra, P. (2009). What is technological pedagogical content knowledge? Journal of Research on Technology in Education. 9(1), 60-70.

Herawati, H. (2010). Empowering learners' autonomy skills: using interactive learning online modules. Language Education: An Essential for a Global Economy, (Series 52), 126-142.

Hung, H. T. (2015). Flipping the classroom for English language learners to foster active learning. Computer Assisted Language Learning, 28(1), 81-96.

Jarvis, W., Halvorson, W., Sadeque, S., \& Johnston, S. (2014). A Large Class Engagement (LCE) model based on Service-Dominant Logic (SDL) and flipped classrooms. Education Research and Perspectives, $41(1), 1-24$.

Kordyban, R., \& Kinash, S. (2013). No more flying on autopilot: the flipped classroom. Educational Technology Solutions, 56, 54-56.

Kukulska-Hulme, A., \& Viberg, O. (2018). Mobile collaborative language learning: state of the art. British Journal of Educational Technology, 49(2), 207-218

Kuswandono, P. (2013). The journey of becoming a teacher: Indonesian pre-service teachers reflecting on their professional learning. Doctoral Dissertation. Melbourne: Monash University.

Lee, G., \& Wallace, A. (2018). Flipped learning in the English as a foreign language classroom: outcomes and perceptions. TESOL Quarterly. 52(1), 62-84, Retrieved from June 2, 2019 from https://doi. org/10.1002/tesq.372

Masduqi, H. (2014). EFL reading in Indonesian universities: perspectives and challenges in cultural contexts. Journal of Teaching and Education, 3(3), 385-397.

Mishra, P., \& Koehler, M. J. (2006). Technological pedagogical content knowledge: a framework for teacher knowledge. Teachers College Record, 108(6), 1017-1054. 
Pasaribu, T. A. (2016). Students' writing anxiety: causes and effects of a Moodle-based writing course. Kotesol Proceedings, 87-96.

Pasaribu, T. A. (2020). Challenging EFL students to read: digital reader response tasks to foster learner autonomy. Teaching English with Technology, 20(2), 21-41.

Pasaribu, T. A., \& Iswandari, Y. A. (2019). A reader response approach in collaborative reading projects to foster critical thinking skills. LLT Journal: A Journal on Language and Language Teaching, 22(2), 246-259.

Pietarinen, J., Soini, T., \& Pyhalto, K. (2014). Students' emotional and cognitive engagement as the determinants of well-being and achievement in school. International Journal of Educational Research, 67, 40-51 https://doi.org/10.1016/j.ijer.2014.05.001

Prasetyawati, O. A. \& Ardi, P. (2020). Integrating Instagram into EFL writing to foster student engagement. Teaching English with Technology, 20(3), 40-62.

Rennie, F. (2008). e-Learning and Social Networking Handbook. In e-Learning and Social Networking Handbook. Retrieved from September 23, 2019 from https://doi.org/10.4324/9780203927762

Reychav, I., Dunaway, M., \& Kobayashi, M. (2015). Understanding mobile technology-fit behaviors outside the classroom. Computers and Education. 87, 142-150.

Spalding, E., \& Wilson, A. (2002). Demystifying reflection: a study of pedagogical strategies that encourage reflective journal writing. Teachers College Record. 104(7), 1393-1421.

Steen-Utheim, A. T., \& Foldnes, N. (2018). A qualitative investigation of student engagement in a flipped classroom. Teaching in Higher Education, 23(3), 307-324

Sung, Y. T., Chang, K. E., \& Yang, J. M. (2015). How effective are mobile devices for language learning? A: a meta-analysis. Educational Research Review, 16, 68-84.

Turan, Z., \& Akdag-Cimen, B. (2020). Flipped classroom in English language teaching: a systematic review. Computer Assisted Language Learning, 33(5-6), 590-606. https://doi.org/10.1080/09588221.20 19.1584117

Webb, M., Doman, E., \& Pusey, K. (2014). Flipping a Chinese university EFL course: what students and teachers think of the model. Journal of Asia TEFL, 11(4), 53-84.

Wulandari, M. (2017). Fostering learning autonomy through the implementation of flipped learning in Language Teaching Media Course. International Journal of Indonesian Education and Teaching, 1(2), 194-205.

Wulandari, M. (2019). Improving EFL learners' speaking proficiency through Instagram Vlog. Journal: A Journal on Language and Language Teaching, 22(1), 111-125.

Wulandari, M., \& Pasaribu, T. A. (2020). Technology for English Language Learning. Yogyakarta: Sanata Dharma University Press.

Yang, Y. T. C., Chuang, Y. C., Li, L. Y., \& Tseng, S. S. (2013). A blended learning environment for individualized English listening and speaking integrating critical thinking. Computers and Education, 63, 285-305.

Yazzie-Mintz, E., \& McCormick, K. (2012). Finding the humanity in the data: Understanding, measuring, and strengthening student engagement. In Handbook of Research on Student Engagement. Retrieved from September 23, 2019 from https://doi.org/10.1007/978-1-4614-2018-7_36

Yunus, M. M., Nordin, N., Salehi, H., Embi, M. A., \& Salehi, Z. (2013). The use of information and communication technology (ICT) in teaching ESL writing skills. English Language Teaching, 6(7), $1-8$.

Zulfikar, T. (2009). The making of Indonesian education: an overview on empowering Indonesian teachers. Journal of Indonesian Social Sciences and Humanities, 2, 13-39. 